\title{
Analisis Termal High Pressure Feedwater Heater di PLTU PT. XYZ
}

\author{
Maria Ulfa Damayanti dan Budi Utomo Kukuh Widodo \\ Jurusan Teknik Mesin, Fakultas Teknologi Industri, Institut Teknologi Sepuluh Nopember (ITS) \\ Jl. Arief Rahman Hakim, Surabaya 60111 Indonesia \\ e-mail: buditem@me.its.ac.id
}

\begin{abstract}
Abstrak-PT. XYZ mengoperasikan tiga unit Pembangkit Listrik Tenaga Uap (PLTU) unit 3, 7 dan 8 berkapasitas 2.030 MegaWatt. Pada PLTU Paiton unit 7 dan 8 terdapat delapan buah feedwater heater yaitu empat buah Low Pressure Water Heater (LPWH), tiga buah High Pressure Water Heater (HPWH), dan sebuah dearator. Pada PLTU Paiton unit 7 dan 8 terdapat kerusakan pada HPWH 6 yang menyebabkan penurunan efisiensi dari siklus secara keseluruhan. Penurunan efisiensi dapat terjadi karena temperatur feedwater sebelum masuk ke boiler terlalu rendah, sehingga kalor yang dibutuhkan oleh boiler untuk memanaskan feedwater meningkat. Oleh karena itu konsumsi batubara akan meningkat dan menyebabkan terjadi kenaikan biaya operasional harian dalam sistem pembangkit. Dari data Divisi Produksi PT. XYZ Unit 7 dan 8 diperoleh spesifikasi HPWH 6, 7, dan 8 dan propertis fluida dalam HPWH 6, 7, dan 8. Data tersebut digunakan sebagai dasar analisis termal yang meliputi performa masing-masing HPH. Tahap selanjutnya dalam analisis termal adalah memvariasikan beban $25 \%, 50 \%, 75 \%$, $100 \%$, dan $105 \%$. Tahap terakhir analisis adalah menghitung performa dengan variasi sumbatan (plug) $5 \%$, $10 \%, 15 \%$, dan $20 \%$ sesuai dengan variasi beban. Hasil yang didapatkan dari penelitian tugas akhir ini adalah nilai effectiveness tertinggi tercapai pada pembebanan $100 \%$ serta menghasilkan pressure drop tertinggi pada pembebanan $105 \%$, nilai effectiveness terbesar serta nilai pressure drop terkecil terjadi pada zona Condensing, serta sumbatan (plugging) pada HPH akan menyebabkan penurunan nilai effectiveness dan kenaikan pressure drop sisi tube.
\end{abstract}

Kata Kunci-Heat exchanger, feedwater heater, effectiveness, pressure drop.

\section{PENDAhUluAN}

S eiring dengan perkembangan zaman dan teknologi, listrik telah menjadi kebutuhan bagi penduduk Indonesia yang berpopulasi tinggi. Perusahaan pembangkit tenaga listrik merupakan sektor terpenting pada setiap negara. Berdasarkan Katalog Statistik PLN 2014, ukuran tingkat ketersediaan listrik PLN di Indonesia pada tahun 2010 - 2014 ditunjukkan pada gambar 1.1.

Pada periode tahun 2015-2024 kebutuhan listrik diperkirakan akan meningkat 219,1 TWh di tahun 2015 menjadi 464,2 TWh di tahun 2024, atau tumbuh rata-rata $8,7 \%$ per tahun. Namun di Indonesia kebutuhan listrik yang sangat besar ini tidak dapat dipenuhi secara optimal oleh Perusahaan Listrik Nasional (PLN). Oleh sebab itu sejak diberlakukannya UU No. 15 Tahun 1985, PP No. 10 Tahun 1989 dan Keputusan Presiden Nomor 37 Tahun 1992, Pemerintah memberikan ijin kepada pihak swasta untuk ikut berpartisipasi dalam usaha ketenagalistrikan di bidang Pembangkit Transmisi dan Distribusi. Salah satu perusahaan swasta yang bergerak dibidang Pembangkit Transmisi dan Distribusi adalah PT. XYZ yang mengoperasikan tiga unit Pembangkit Listrik Tenaga Uap (PLTU) berkapasitas 2.030 MegaWatt.

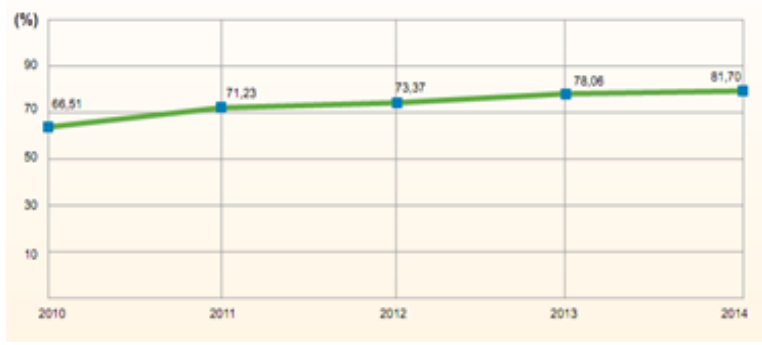

Gambar 1. Rasio Elektrifikasi di Indonesia Tahun 2010-2014

Pada PLTU Paiton unit 7 dan 8 terdapat delapan buah feedwater heater yaitu empat buah Low Pressure Water Heater (LWH), tiga buah High Pressure Water Heater (HPH), dan sebuah dearator. Pada PLTU Paiton unit 7 dan 8 terdapat kerusakan pada HPH 6 yang menyebabkan penurunan efisiensi dari siklus secara keseluruhan. Hal ini dapat terjadi karena temperature fluida kerja sebelum masuk ke boiler terlalu rendah, sehingga kalor yang dibutuhkan oleh boiler meningkat. Oleh karena itu konsumsi batubara untuk memanaskan boiler meningkat dan selanjutnya menaikkan biaya operasional harian dalam sistem pembangkit.

Penelitian ini akan membahas HPH (High Pressure Water Heater) yang ada pada PT. XYZ unit 7 dan 8 . Ada 3 buah High Pressure Water Heater yaitu HPH 6, 7 dan 8. HPH 6, 7, dan 8 merupakan shell and tube heat exchanger tipe U-Tube. Salah satu kerusakan yang sering terjadi adalah kebocoran tube. Kebocoran tube menyebabkan penambahan tekanan steam di dalam shell serta akan mempengaruhi proses perpindahan panas di HPH selanjutnya. Salah satu solusi untuk mengatasi kebocoran tube di HPH adalah menyumbat ujung tube yang bocor (plugging) agar tube tidak teraliri air.

Plugging yang dilakukan pada HPH memiliki batas maksimal. Jika plugging melebihi batasan maksimal, akan terjadi penurunan performa dari HPH. Oleh karena itu perlu dilakukan analisis termal untuk mengetahui peforma HPH dengan variasi beban dan jumlah sumbatan yang diberikan kepada HPH tersebut.

\section{URAIAN ANALISIS}

\section{A. High Pressure Water Heater}

High Pressure Water Heater memiliki tiga zona utama yaitu zona desuperheating, zona condensing, dan zona subcooling. Zona Desuperheating adalah zona dimana uap panas lanjut yang masuk ke dalam HPH akan 
mengalami penurunan temperatur hingga mencapai temperatur uap jenuh. Zona Condensing merupakan zona dimana uap jenuh mengalami perubahan fase menjadi cair jenuh.

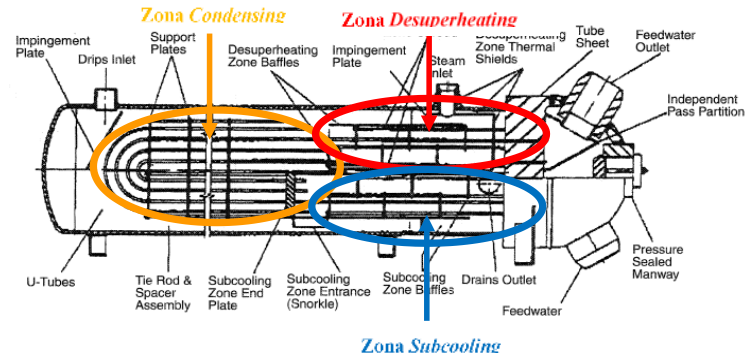

Gambar 2. Feedwater heater dan bagian-bagiannya

Pada zona ini uap tidak mengalami perubahan temperatur tetapi hanya mengalami perubahan fase. Zona Subcooling merupakan zona penurunan temperatur uap yang telah berubah fase menjadi cair jenuh hingga mencapai temperatur subcool. Selanjutnya drain dari zona Subcooling ini akan dialirkan ke feedwater heater yang bertekanan lebih rendah. Pada Gambar 2 dapat dilihat bagian-bagian dan posisi zona-zona yang terdapat pada High Pressure Water Heater.

\section{B. Kesetimbangan Energi di HPH 6, 7, dan 8}

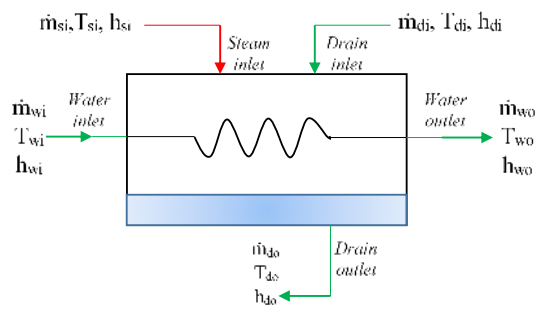

Gambar 3. Balance Energy HPH 6 dan 7

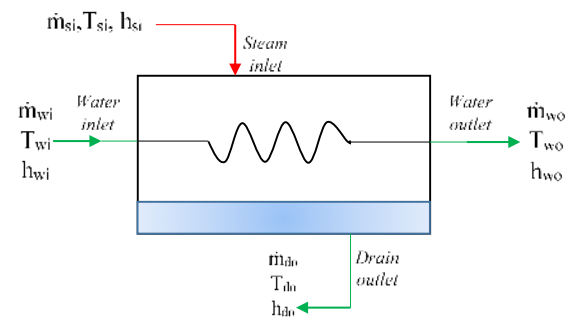

Gambar 4. Balance Energy HPH 8

Kesetimbangan energi untuk HPH 6 dan 7 ditunjukan pada Gambar 3 serta untuk HPH 8 ditunjukkan Gambar 4 Analisis secara termodinamika dilakukan pada kondisi steady state, tidak ada kerja, serta perubahan energi kinetik dan potensial diabaikan, sehingga persamaan konservasi energi pada HPH 6, 7, dan 8 pada persamaan 1,2 , dan 3 .

$\dot{\mathrm{m}}_{s i, 6} \boldsymbol{h}_{s i, 6}+\dot{\mathrm{m}}_{w i, 6} \boldsymbol{h}_{w i, 6}+\dot{\mathrm{m}}_{d i, 6} \boldsymbol{h}_{d i, 6}=\dot{\mathrm{m}}_{w o, 6} \boldsymbol{h}_{w o, 6}+$ $\dot{\mathrm{m}}_{\boldsymbol{d o , 6}, \boldsymbol{h}} \boldsymbol{h}_{d o, 6}$

$\dot{\mathrm{m}}_{s i, 7} \boldsymbol{h}_{s i, 7}+\dot{\mathrm{m}}_{w i, 7} \boldsymbol{h}_{w i, 7}+\dot{\mathrm{m}}_{d i, 7} \boldsymbol{h}_{d i, 7}=\dot{\mathrm{m}}_{w o, 7} \boldsymbol{h}_{w o, 7}+$

$\dot{\mathrm{m}}_{\boldsymbol{d o}, 7} \boldsymbol{h}_{\boldsymbol{d o}, 7}$

$\dot{\mathrm{m}}_{s i, 8} \boldsymbol{h}_{s i, 8}+\dot{\mathrm{m}}_{w i, 8} \boldsymbol{h}_{w i, 8}=\dot{\mathrm{m}}_{w o, 8} \boldsymbol{h}_{w o, 8}+\dot{\mathrm{m}}_{d o, 8} \boldsymbol{h}_{d o, 8}(3)$

\section{Analisis Perpindahan Panas Sisi Shell}

Perpindahan panas yang terjadi di luar tube (sisi shell) dianalisis berdasarkan perpindahan panas secara konveksi yang melewati susunan tube pada heat exchanger. Besarnya perpindahan panas yang terjadi sangat dipengaruhi oleh turbulensi aliran dan jumlah tube. Tingkat turbulensi aliran dapat dilihat melalui Reynolds number. Dengan mengetahui kecepatan maksimumnya, maka nilai Reynolds number dapat dihitung menggunakan persamaan 4 .

$$
\boldsymbol{R} \boldsymbol{e}_{D, \max }=\frac{\dot{m} \cdot D_{e}}{A_{s} \cdot \mu}
$$

Secara umum koefisien perpindahan panas rata-rata untuk aliran fluida melewati tube banks dalam shell dapat diperoleh dengan persamaan berikut:

$\overline{\boldsymbol{h}}=\frac{N u_{D} \cdot k}{D_{e}}$

$\bar{N} \bar{u}_{D}=0,36 \cdot \operatorname{Re}^{0.55} \cdot \operatorname{Pr}^{1 / 3} \cdot\left(\frac{\mu_{b}}{\mu_{w}}\right)^{0.14}$

$\overline{N u}_{D}=0,36 \cdot\left(\frac{\dot{m} \cdot D_{e}}{A_{s} \cdot \mu_{b}}\right)^{0.55} \cdot \operatorname{Pr}^{1 / 3} \cdot\left(\frac{\mu_{b}}{\mu_{w}}\right)^{0.14}$

\section{Analisis Perpindahan Panas Sisi Tube}

Perpindahan panas yang terjadi di dalam tube dianalisis berdasarkan perpindahan panas yang terjadi pada aliran internal. Persamaan yang dapat digunakan untuk menghitung nilai Reynolds number ditunjukkan pada persamaan 8 .

$$
\boldsymbol{R} \boldsymbol{e}_{t}=\frac{\boldsymbol{u}_{t} \rho d_{i}}{\mu}
$$

Pada circular tube dengan karakteristik uniform surface heat flux and laminar serta fully developed conditions, nilai Nusselt number merupakan suatu konstanta yang besarnya tidak bergantung pada $\mathrm{Re}_{\mathrm{d}}, \mathrm{Pr}$ dan axial location. Persamaan 8 dan 9 merupakan persamaan yang digunakan untuk menghitung nilai Nusselt number pada aliran laminar $(\operatorname{Re}<2300)$.

$$
\begin{aligned}
& N u_{D}=\frac{h D}{k}=4.36\left(q^{\prime \prime}=\text { konstan }\right) \\
& N u_{D}=3.66(\text { Ts }=\text { konstan })
\end{aligned}
$$

Berdasarkan Petukhov-Kirillov correlation, nilai Nusselt number pada aliran turbulent ( $\operatorname{Re}>2300)$ dapat dihitung sebagai,

$\boldsymbol{N u}=\frac{\left(\frac{f}{2}\right) \operatorname{Re} \operatorname{Pr}}{1,07+12,7\left(\frac{f}{2}\right)^{1 / 2}\left(\operatorname{Pr}^{\frac{2}{3}}-1\right)}$

dengan $f=(1,58 \ln R e-3,28)^{-2}$

\section{E. Analisis Pressure drop Shell Side}

Nilai pressure drop pada zona Desuperheating dapat dicari menggunakan persamaan 12 .

$\Delta \boldsymbol{P}_{\text {des }}=\frac{f \times G s^{2} \times D_{s} x(N b+1)}{2 \times \rho \times D_{e} x\left(\frac{\mu_{b}}{\mu_{w}}\right)^{0.14}}$

Nilai pressure drop pada zona Condensing dicari dengan pendekatan pressure drop aliran 2 fase pada shell. Total pressure drop pada aliran 2 fase yang melewati tube bundle meliputi static pressure drop akibat elevasi, momentum pressure drop akibat kecepatan dan frictional pressure drop akibat gesekan. Algoritma untuk mendapatkan total pressure drop adalah sebagai ditunjukkan pada persamaan 13.

$\Delta \boldsymbol{P}_{\text {total }}=\left(\frac{d p}{d z}\right)_{f r}+\left(\frac{d p}{d z}\right)_{m o}+\left(\frac{d p}{d z}\right)_{g r}$

Perhitungan static pressure drop ditunjukkan pada persamaan 14 .

$\left(\frac{d p}{d z}\right)_{g r}=\frac{g}{g_{c}} \sin \theta\left[\alpha \rho_{g}+(1-\alpha) \rho_{l}\right]$

Momentum pressure drop ditunjukkan pada persamaan 15 .

$\left(\frac{d p}{d z}\right)_{m o}=\frac{d}{d z}\left[\frac{G_{s}^{2}}{g_{c}}\left(\frac{x^{2}}{\alpha \rho_{g}}+\frac{(1-x)^{2}}{(1-\alpha) \rho_{l}}\right)\right]$ 
$\alpha=\left[1+A\left(\frac{1-x}{x}\right)^{p}\left(\frac{\rho_{g}}{\rho_{l}}\right)^{q}\left(\frac{\mu_{l}}{\mu_{g}}\right)^{r}\right]^{-1}$

Friction pressure drop ditunjukkan pada persamaan 17.

$$
\begin{aligned}
& \left(\frac{d p}{d z}\right)_{f r}=\left(\frac{d p}{d z}\right)_{f r, l} \varphi_{l}^{2} \\
& \left(\frac{d p}{d z}\right)_{f r, l}=\frac{4 f_{l} G_{s}{ }^{2}}{2 g_{c} \rho_{l} D_{h}} \\
& \varphi_{l}^{2}=1+\frac{c}{X}+\frac{1}{X^{2}} \\
& X^{2}=\frac{f_{l} \rho_{g}}{f_{g} \rho_{l}}
\end{aligned}
$$

Nilai pressure drop pada zona Subcooling dapat dicari menggunakan persamaan 21 .

$\Delta P=\frac{f \times G s^{2} \times D_{s} \times\left(N_{b}+1\right)}{2 \times \rho \times D_{e} \times\left(\frac{\mu_{b}}{\mu_{w}}\right)^{0.14}}$

\section{F. Thermal Resistance}

Thermal resistance adalah total tahanan termal antar dua fluida yang terjadi proses perpindahan panas. Nilai thermal resistance dapat dihitung menggunakan persamaan 22 .

$\boldsymbol{R}_{\text {tot }}=\frac{1}{\boldsymbol{U A}}$

Karena nilai tahanan yang terdapat pada sistem berupa tahanan termal akibat konveksi aliran dalam tube, konduksi pada material silinder dan konveksi aliran di luar tube, maka persamaan untuk tahanan termal total pada sistem dapat dihitung dengan persamaan 23 .

$$
R_{\text {tot }}=\frac{1}{h_{1} 2 \pi r_{1} L}+\frac{\ln \left(\frac{r_{2}}{r_{1}}\right)}{2 \pi k L}+\frac{1}{h_{2} 2 \pi r_{2} L}
$$

G. Analisis Heat exchanger dengan metode Number of Transfer Unit (NTU)

Metode ini digunakan untuk mengetahui unjuk kerja (effectiveness) dari heat exchanger. Hal pertama yang harus diketahui ialah nilai laju perpindahan panas maksimum $\left(\mathrm{q}_{\max }\right)$ dari heat exchanger.

Jika $\mathrm{C}_{\mathrm{c}}<\mathrm{C}_{\mathrm{h}}$, maka $\boldsymbol{q}_{\text {maks }}=\mathrm{C}_{\mathrm{c}}\left(\mathbf{T}_{\mathrm{h}, \mathrm{i}}-\mathrm{T}_{\mathrm{c}, \mathrm{i}}\right)$

Jika $\mathrm{C}_{\mathrm{c}}>\mathrm{C}_{\mathrm{h}}$, maka $q_{\text {maks }}=\mathrm{C}_{\mathrm{h}}\left(\mathrm{T}_{\mathrm{h}, \mathrm{i}}-\mathrm{T}_{\mathrm{c}, \mathrm{i}}\right)$

$\mathrm{C}$ adalah notasi untuk heat capacity rate. Nilai heat capacity rate yang digunakan adalah nilai terkecil antara heat capacity rate pada fluida panas $\left(\mathrm{C}_{\mathrm{h}}\right)$ dan heat capacity rate pada fluida dingin $\left(\mathrm{C}_{\mathrm{c}}\right)$ yang dinotasikan $\mathrm{C}_{\text {min }}$. Nilai $\mathrm{C}_{\mathrm{h}}$ dan $\mathrm{C}_{\mathrm{c}}$ ditunjukkan pada persamaan 26 dan 27.

$\boldsymbol{C}_{c}=\dot{\boldsymbol{m}}_{\boldsymbol{c}} \cdot \boldsymbol{c}_{\boldsymbol{p}_{\boldsymbol{c}}}$

$\boldsymbol{C}_{\boldsymbol{h}}=\dot{\boldsymbol{m}}_{\boldsymbol{h}} \cdot \boldsymbol{c}_{\boldsymbol{p}_{\boldsymbol{h}}}$

Effectiveness $(\varepsilon)$ adalah perbandingan antara laju perpindahan panas heat exchanger dengan laju perpindahan maksimum yang dimungkinkan (persamaan 28).

$\boldsymbol{\varepsilon}=\frac{\boldsymbol{q}}{\boldsymbol{q}_{\text {maks }}}$

Effectiveness merupakan bilangan tanpa dimensi dan berada dalam batas $0<\varepsilon<1$. Untuk semua heat exchanger effectiveness dapat dinyatakan pada persamaan 29 .

$\varepsilon=f\left(N t u, \frac{C_{\text {min }}}{C_{\text {maks }}}\right)$

Number of Transfer Unit (NTU) juga merupakan bilangan tanpa dimensi dan didefinisikan sebagai persamaan 30 .
$N T U=\frac{U \cdot A}{C_{\min }}$

\section{HASIL DAN ANALISIS}

A. Effectiveness HPH 6, 7, dan 8 pada Zona Desuperheating, Condensing, dan Subcooling

Pada gambar 5, 6, dan 7 terlihat bahwa pada zona Desuperheating, Condensing dan Subcooling mengalami peningkatan effectiveness seiring dengan bertambahnya

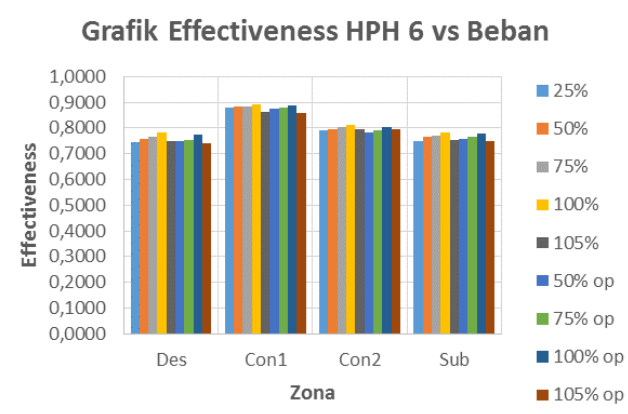

Gambar 5. Grafik Effectiveness HPH 6 vs Beban

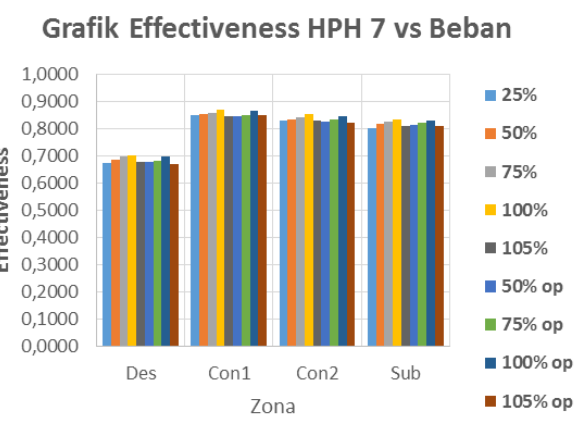

Gambar 6. Grafik Effectiveness HPH 7 vs Beban

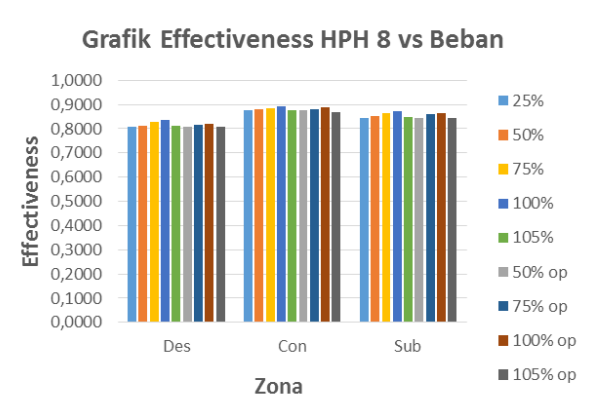

Gambar 7. Grafik Effectiveness HPH 8 vs Beban

Beban yang diterima oleh HPH. Nilai effectiveness terbesar terjadi pada pembebanan $100 \%$.

Hal ini terjadi karena adanya kenaikan nilai NTU. Nilai NTU dipengaruhi oleh perbandingan antara nilai overall heat transfer (U) dan Cmin. Perbandingan nilai $U$ dan Cmin semakin besar seiring dengan bertambahnya pembebanan. Selain itu peningkatan effectiveness juga dipengaruhi oleh penurunan nilai rasio kapasitas panas (Cr). Penurunan $\mathrm{Cr}$ disebabkan oleh penurunan perbandingan antara $\mathrm{C}_{\min }$ dan $\mathrm{C}_{\text {maks. }}$ Penurunan perbandingan nilai $\mathrm{C}_{\min } \quad\left(\mathrm{C}_{\text {hot }}\right)$ dan $\mathrm{C}_{\text {maks }} \quad\left(\mathrm{C}_{\text {cold }}\right)$ disebabkan oleh menurunnya perbandingan perkalian antara massflow rate sisi hot dan kalor spesifik sisi hot dan perkalian antara massflow rate sisi cold dan kalor spesifik sisi cold seiring dengan bertambahnya beban.

Selain itu pada grafik juga dapat dilihat bahwa nilai effectiveness terbesar terjadi pada zona Condensing. Hal itu dapat dilihat pada grafik HPH 6, 7 dan 8. Hal ini karena nilai NTU terbesar dimiliki oleh zona 
Condensing. Nilai NTU yang besar ini didapat karena pada zona Condensing memiliki nilai Cmin yang paling kecil diantara zona yang lain. Selain itu nilai $\mathrm{Cr}$ pada zona Condensing merupakan nilai $\mathrm{Cr}$ terendah sehingga menyebabkan nilai effectiveness pada zona Condensing memiliki nilai terbesar.

\section{B. Analisis Effectiveness HPH Secara Keseluruhan}

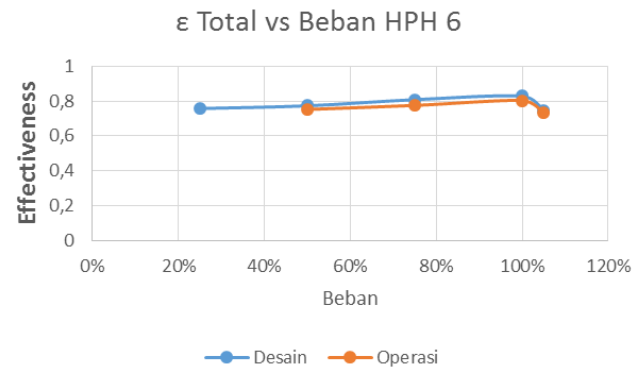

Gambar 8. $\varepsilon$ Total vs Beban HPH 6

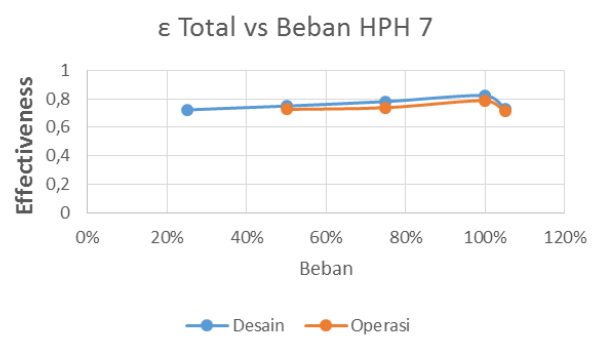

Gambar 9. $\varepsilon$ Total vs Beban HPH 7

$\varepsilon$ Total vs Beban HPH 8

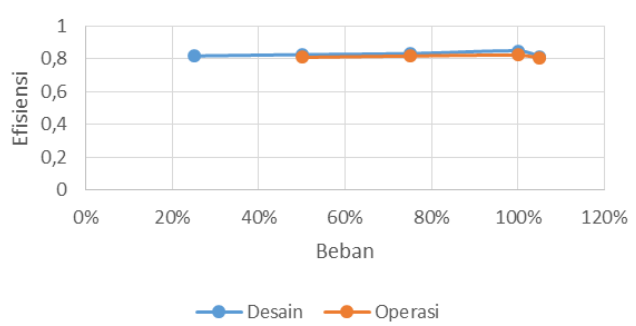

Gambar 10. $\varepsilon$ Total vs Beban HPH 6

Pada gambar 8, 9, dan 10 terlihat bahwa seiring dengan bertambahnya beban yang diterima oleh HPH, maka akan terjadi peningkatan effectiveness. Nilai effectiveness terbesar terjadi pada pembebanan $100 \%$. Hal ini terjadi karena adanya peningkatan nilai NTU. Nilai NTU dipengaruhi oleh perbandingan antara nilai overall heat transfer (U) dan $\mathrm{C}_{\min }$. Perbandingan nilai $\mathrm{U}$ dan $\mathrm{C}_{\min }$ semakin besar seiring dengan bertambahnya pembebanan. Selain itu penurunan effectiveness juga dipengaruhi oleh penurunan nilai rasio kapasitas panas (Cr). Penurunan $\mathrm{Cr}$ disebabkan oleh penurunan perbandingan antara $\mathrm{C}_{\text {min }}$ dan $\mathrm{C}_{\text {maks. }}$ Penurunan perbandingan nilai $\mathrm{C}_{\min } \quad\left(\mathrm{C}_{\text {hot }}\right)$ dan $\mathrm{C}_{\text {maks }} \quad\left(\mathrm{C}_{\text {cold }}\right)$ disebabkan oleh penurunan perbandingan perkalian antara massflow rate sisi hot dan kalor spesifik sisi hot dan perkalian antara massflow rate sisi cold dan kalor spesifik sisi cold seiring dengan bertambahnya beban.

Pada gambar 8, 9, dan 10 juga dapat dilihat bahwa nilai effectiveness HPH 6, 7, dan 8 pada kondisi operasi lebih rendah dari pada kondisi design. Hal ini mengartikan bahwa terjadi penurunan nilai effectiveness.
C. Nilai Effectiveness dan Pressure drop Tube Side HPH 6, 7, dan 8 dengan Variasi Plugging

Pada gambar 11, 12, dan 13 dapat dilihat bahwa semakin besar persentase plug maka nilai effectiveness semakin menurun. Hal ini dikarenakan bertambah besarnya nilai koefisien konveksi. Bertambahnya nilai ini dikarenakan meningkatnya kecepatan aliran fluida yang disebabkan berkurangnya luasan permukan yang dilalui oleh aliran fluida.

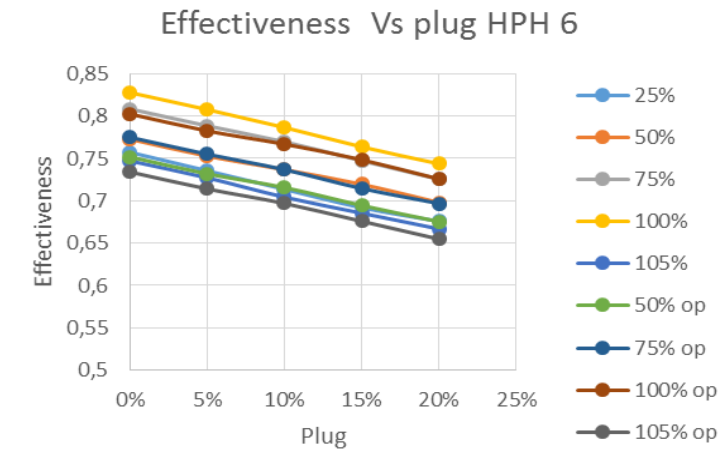

Gambar 11. $\varepsilon$ Vs plug HPH 6

Effectiveness Vs plug HPH 7

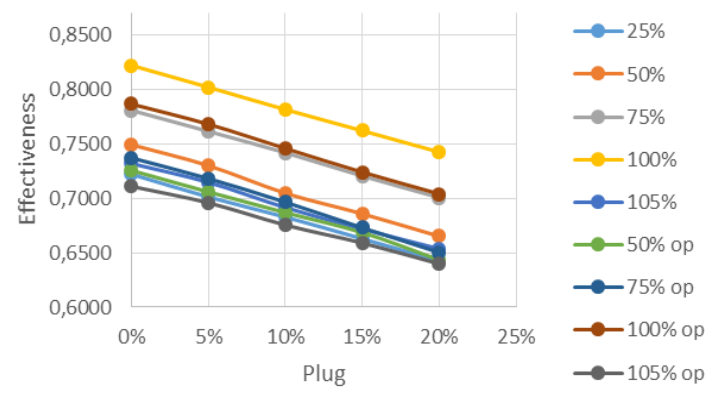

Gambar 12. $\varepsilon$ Vs plug HPH 7

Effectiveness Vs plug HPH 8

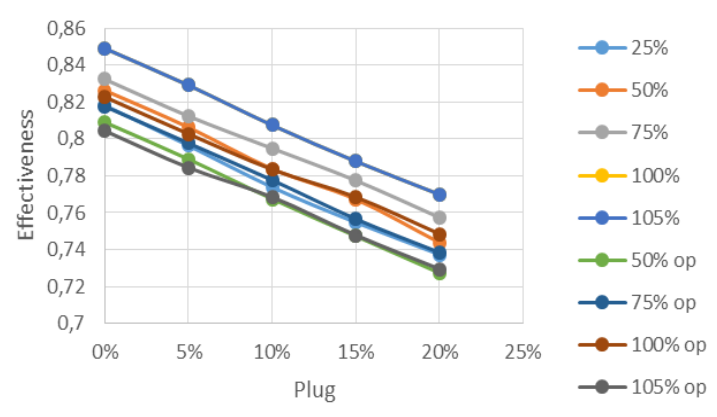

Gambar 13. $\varepsilon$ Vs plug HPH 8

Jumlah tube berpengaruh pada nilai laju perpindahan panas karena kecepatan yang melintas di sisi tube akan semakin kecil seiring dengan penambahan jumlah tube. Sebaliknya, apabila jumlah tube yang dibutuhkan untuk HPH semakin sedikit, kecepatan aliran yang melintas di sisi tube akan semakin besar sehingga mengakibatkan nilai laju perpindahan panas secara konveksi didalamnya semakin besar pula. Dengan bertambahnya nilai laju perpindahan panas secara konveksi maka akan meningkatkan nilai overall heat transfer. Namun peningkatan nilai overall heat transfer diiringi dengan berkurangnya luasan perpindahan panas, sehingga menyebabkan nilai NTU akan menjadi kecil. Karena Nilai NTU yang kecil inilah yang menyebabkan 
menurunnya nilai effectiveness seiring dengan bertambahnya plugging.

Analisis pressure drop tube side dengan pengaruh plug memberikan hasil yang dapat dinyatakan dalam grafik sebagai berikut.

$\triangle \mathrm{P}$ Tube Side Vs plug HPH 6

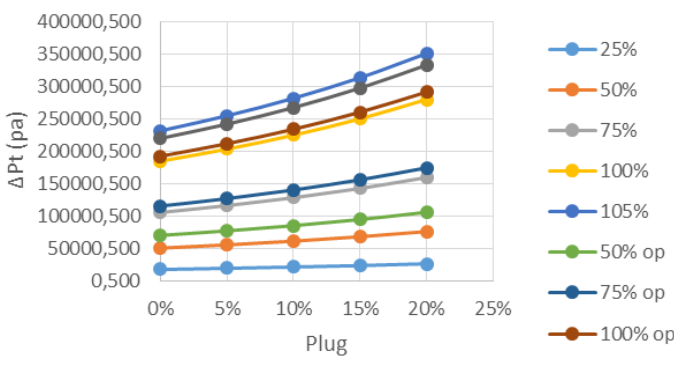

Gambar 14. $\Delta$ Pt Vs plug HPH 8

$\triangle \mathrm{P}$ Tube Side Vs plug HPH 7

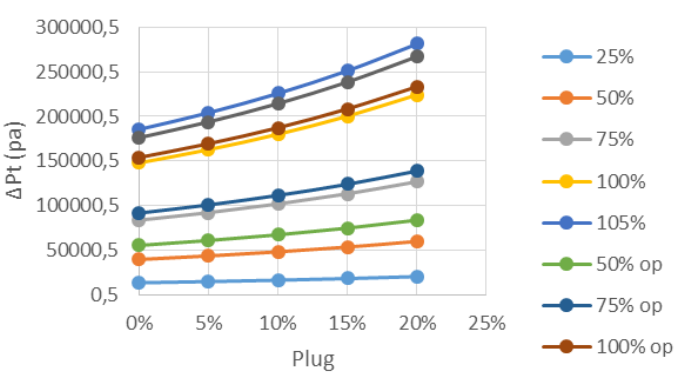

Gambar 15. $\Delta$ Pt Vs plug HPH 8

$\triangle \mathrm{P}$ Tube Side Vs plug HPH 8

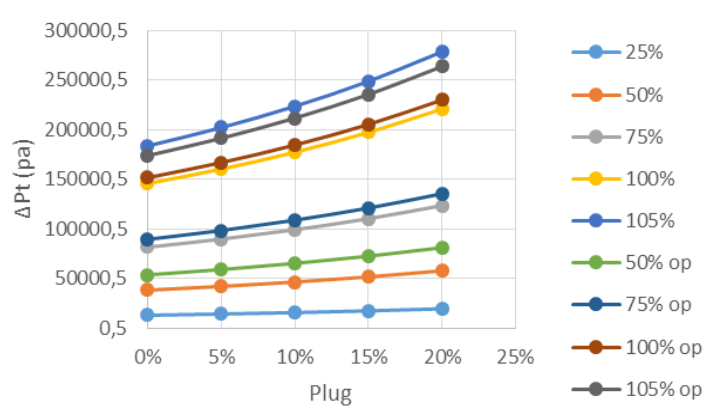

Gambar 16. $\Delta \mathrm{Pt}$ Vs plug HPH 8

Pada gambar 15, 16, dan 17 dapat dilihat bahwa semakin besar nilai plugging maka nilai pressure drop semakin besar. Apabila jumlah tube yang disumbat semakin banyak, dengan mass flowrate yang tetap, maka kecepatan aliran di dalam tube akan semakin besar sehingga nilai Reynolds number juga akan meningkat. Peningkatan nilai Reynolds number sebanding dengan peningkatan nilai pressure drop. Semakin besar nilai Reynolds number, maka nilai pressure drop yang terjadi akan semakin tinggi.

Selain itu dapat dilihat pula bahwa seiring meningkatnya beban, nilai pressure drop pada tube akan juga meningkat. Peningkatan ini disebabkan oleh peningkatan massflow rate pada tube. Dengan meningkatnya massflow rate, maka kecepatan aliran di dalam tube akan semakin meningkat. Peningkatan nilai Reynolds number menyebabkan nilai pressure drop yang terjadi akan semakin tinggi.
D. Nilai Pressure drop HPH 6, 7, dan 8 pada Zona Desuperheating, Condensing, dan Subcooling

Dari grafik dapat dilihat bahwa nilai pressure drop terkecil terjadi pada zona Condensing. Selain itu di zona Desuperheating memiliki nilai pressure drop paling besar diantara zona Condensing dan Subcooling.

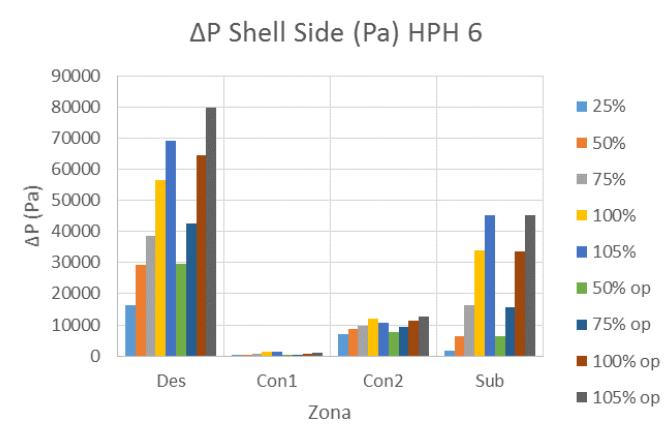

Gambar 17. $\triangle$ Ps HPH 6 Vs Beban

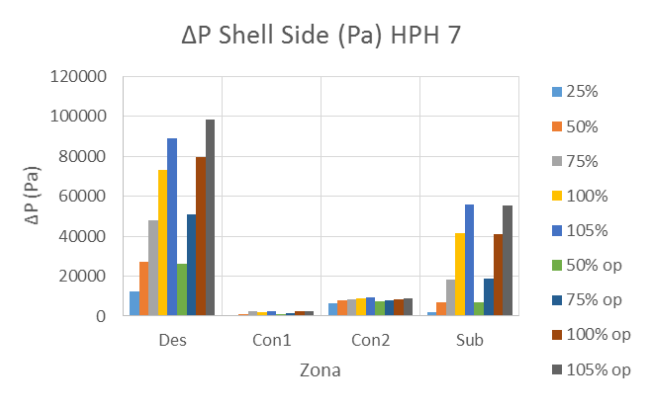

Gambar 18. $\triangle$ Ps HPH 6 Vs Beban

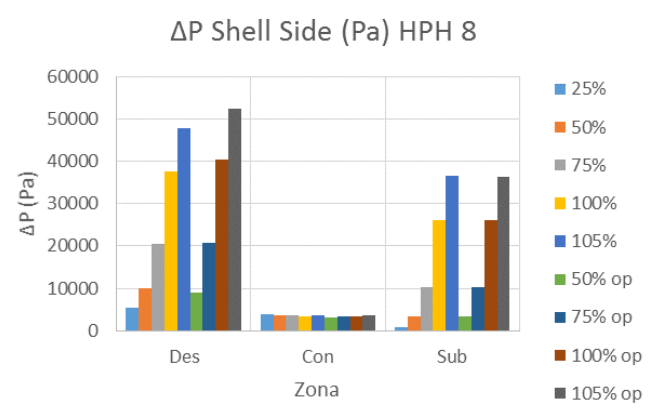

Gambar 19. $\triangle$ Ps HPH 6 Vs Beban

Hal ini dikarenakan zona Desuperheating memiliki nilai baffle spacing yang kecil. Nilai baffle spacing berbanding terbalik dengan nilai pressure drop. Semakin besar nilai baffle spacing, maka luasan area yang dilalui aliran semakin besar, mengakibatkan kecepatan aliran massa akan semakin kecil sehingga nilai pressure drop yang terjadi pada aliran juga semakin turun. Selain itu aliran fluida pada zona Desuperheating memiliki massa jenis yang paling kecil dibanding zona Condensing dan Desuperheating. Nilai massa jenis inilah yang menyebabkan tingginya pressure drop. Hal ini menandakan bahwa semakin kecil nilai massa jenis suatu aliran fluida, maka akan menyebabkan peningkatan nilai pressure drop.

Nilai pressure drop pada zona Condensing dipengaruhi oleh besarnya pressure drop akibat momentum, friction, dan gravity. Nilai friction pressure drop pada zona Condensing 1 lebih kecil dibanding zona Condensing 2. Hal ini dikarenakan laju alir massa yang melewati zona Condensing 1 lebih kecil dibanding laju alir massa yang melewati zona Condensing 2. Laju alir massa akan memengaruhi nilai pressure drop. Semakin 
besar nilai laju alir massa, maka nilai pressure drop akan semakin meningkat. Pertambahan nilai laju alir massa di zona Condensing 2 disebabkan oleh adanya aliran fluida tambahan yang masuk ke drain inlet. Selain itu hal yang memberikan kontribusi besar terhadap peningkatan nilai pressure drop pada zona Condensing ialah gravity pressure drop. Nilai gravity pressure drop pada zona Condensing 1 lebih kecil dibanding zona Condensing 2. Hal ini dikarenakan kualitas fluida pada zona Condensing 1 lebih besar dibanding kualitas fluida pada zona 2. Semakin kualitas fluida mendekati angka 1 maka nilai gravity pressure drop semakin kecil. Nilai kualitas fluida yang mendekati angka 1 menandakan bahwa kandungan uap yang terdapat pada fluida tersebut besar. Nilai pressure drop pada zona Condensing merupakan nilai pressure drop terkecil dibanding nilai pressure drop pada zona-zona yang lain. hal ini juga dipengaruhi oleh nilai baffle spacing di zona Condensing. Zona Condensing memiliki nilai baffle spacing paling besar diantara zona-zona yang lain.

Dari grafik juga dapat dilihat bahwa semakin besar nilai pembebanan, maka nilai pressure drop pada shell akan semakin meningkat, hal ini dipengaruhi oleh peningkatan laju alir massa fluida yang melewati sisi shell. Peningkatan pembebanan pada HPH diiringi oleh peningkatan laju alir massa fluida.

\section{KESIMPULAN DAN SARAN}

Berdasarkan Analisis termal yang telah dilakukan berdasarkan data heat balance dan data operasi High Pressure Heater 6, 7, dan 8 PT. XYZ memberikan kesimpulan sebagai berikut.

1. Effectiveness tertinggi tercapai pada pembebanan $100 \%$ sebesar 0,83 untuk HPH 6, 0,82 untuk HPH 7, dan 0,85 untuk HPH 8 berdasarkan data design dan 0,80 untuk HPH 6, 0,79 untuk HPH 7, dan 0,82 untuk HPH 8 berdasarkan data operasi.

2. Pressure drop tertinggi di sisi tube pada pembebanan 105\% sebesar 231445,40 Pa untuk HPH 6, 185488,81 $\mathrm{Pa}$ untuk HPH 7, dan 0,8228 untuk HPH 8 berdasarkan data design dan 219693,09 Pa untuk HPH 6, 176198,28 Pa untuk HPH 7, untuk 173933,48 Pa HPH 8 berdasarkan data operasi.

3. Nilai effectiveness terbesar serta nilai pressure drop terkecil sebesar 0,89 dan 382,82 Pa untuk HPH 6, 0,87 dan 392,50 Pa untuk HPH 7, serta 0,89 dan $11400,53 \mathrm{~Pa}$ untuk HPH 8 terjadi pada zona Condensing.

4. Sumbatan (plugging) sebesar 20\% pada HPH akan menyebabkan penurunan nilai effectiveness dan kenaikan pressure drop sebesar sisi tube sebesar $10,15 \%$ dan 33,99\% untuk HPH $6,9,67 \%$ dan $34,01 \%$ untuk HPH 7, serta 9,5\% dan 34,052\% untuk HPH 7
Saran yang diberikan oleh penulis dalam tugas akhir ini yaitu:

1. Perlu adanya penelitian lanjut mengenai fenomena fisik yang terjadi di dalam High Pressure Heater.

2. Perlu adanya data tambahan untuk mempermudah analisis High Pressure Heater.

\section{UCAPAN TERIMA KASIH}

Penulis berterimakasih kepada Bapak dosen penelaah Bb. Arip Dwiyantoro, ST, M.Eng, PhD. seluruh pihak yang telah membantu dan seluruh staf jurusan Teknik Mesin ITS Surabaya yang telah memberikan banyak pelajaran berharga kepada penulis.

\section{DAFTAR PUSTAKA}

[1] 2014. Statistik PLN 2014. Jakarta: Sekertariat Perusahaan PT PLN (Persero).

[2] Incropera, Frank P. Dewitt, David P. Bergman, Theodore L. Lavine, Adrienne S. 2007. Fundamentals of Heat and Mass Transfer. John Wiley \& Sons (Asia) PteLtd: Hoboken.

[3] Moran, Michael J. Shapiro, Howard N. 2005. Fundamentals of Engineering Thermodynamics. John Wiley \& Sons Ltd, the Atrium, Shouthern Gate, Chichester, West Sussex PO19 8SQ: England.

[4] Kakac, Sadic. Liu, Hongtan. 2002. Heat Exchanger Selections, Rating, and Thermal Design. CRC Press LLC, 2000 N. W. Corporate Blvd: Boca Raton, Florida.

[5] Hussaini, Irfan S., Syed M. Zubair, M.A. Antar. 2006. Area Allocation in multi-zone feedwater heaters. International Journal of Heat and Mass Transfer 49.

[6] Febriati, Warida. 2015. Re-Design High Pressure Heater (Hph) 6 Di Pltu Unit 3 PT. Pembangkitan Jawa-Bali Unit Pembangkitan Gresik Dengan Analisis Termodinamika Dan Perpindahan Panas. Tugas Akhir. Tidak dipublikasikan. Surabaya: Institut Teknologi Sepuluh Nopember.

[7] Suradika, Dharmaji. 2011. Re-design dan recalculation High Pressure Heater (HPH) 7 PT. PJB UP Paiton pada Zona Desuperheating Menggunakan Analisis Termodinamika dan Perpindahan Panas. Tugas Akhir. Tidak dipublikasikan. Surabaya: Institut Teknologi Sepuluh Nopember.

[8] W, Findra Satria. 2010. Analisa Perpindahan Panas Pengaruh Tube Plugging Terhadap Perfomansi Heat Exchanger MCR. Compressor Intercooler G4-E-5a/B (Studi Kasus Di Pt Badak Ngl Bontang). Tugas Akhir. Tidak dipublikasikan. Surabaya: Institut Teknologi Sepuluh Nopember.

[9] Shah, Ramesh K. and Dusan P. Sekulic. 1998. Fundamental of Heat Exchangers Design. New York: John Wiley \& Sons, Inc. 